Joanna Rutkowiak emer. prof. Uniwersytetu Gdańskiego https://doi.org/10.26881/ae.2019.16.01 joannarut1@gmail.com

\title{
Rancière'owskie interpretacje emancypacyjne: doświadczanie pracy akademickiej w uczelniach niepublicznych na ziemi warmińsko-mazurskiej
}

\section{Wstęp}

Wbrew tytułowi niniejszego artykułu jego tematem nie jest problematyka etniczności. Jest to tekst dydaktyczny, tyle że do przedstawionych w nim wydarzeń edukacyjnych doszło na terenie Warmii i Mazur, co jest znaczące dla meritum podjętej kwestii.

Owo meritum dotyczy podnoszenia poziomu wykształcenia Polaków, a dokładniej wyrównywania startu młodzieży do szkół wyższych realizowanego po zmianie systemowej w roku 1989, w warunkach demokratyzującej się Polski. Było to szczególnie znaczące dla tych części kraju, które odziedziczyły po historii duże braki oświatowe i komplikacje kulturowe, tworzące horyzontalne nierówności edukacyjne (Zawistowska 2012), a należały do nich - między innymi - tereny Warmii i Mazur (Malewska 2006).

Wzrost liczby studiujących - sukces czy rozczarowanie?

Po czasach realnego socjalizmu odziedziczyliśmy niską skolaryzację - szczególnie na poziomie szkolnictwa średniego ogólnokształcącego i wyższego. W 1990 roku współczynnik skolaryzacji netto dla kształcenia wyższego wynosił 12,9\%. Następnie w 2008 roku było to już 52,7\% odpowiedniej wiekowo części populacji, rozłożonej nierównomiernie w skali kraju. Obecnie, pomimo spadku liczby studiujących około roku 2015, nadal utrzymuje się wysoki poziom odsetka studiujących.

Udostępnianie kształcenia realizowano przez zwiększenie liczby liceów ogólnokształcących, wzrost limitów przyjęć do publicznych szkól wyższych oraz 
uruchamianie wyższych szkół niepublicznych, które pojawiały się wówczas w kraju lawinowo. Te zmiany, które objęły także Warmię i Mazury, wywoływały krańcowo różne oceny.

Z jednej strony dodatnio wartościowano rosnący dostęp do wyższego wykształcenia, sprzyjający zaspokajaniu aspiracji Polaków do jego osiągania. Łączono to z przyspieszeniami rozwojowymi krajowych i regionalnych potencjałów wytwórczych oraz przygotowaniem ludzi do obywatelskiej partycypacji, znaczącej w warunkach zmiany ustrojowej.

Z drugiej strony liczne były i nadal są głosy krytyki. Odnoszą się one do obniżania poziomu kształcenia, które jest coraz bardziej umasowione, realizowane $\mathrm{z}$ udziałem młodzieży ze środowisk o skromnych zasobach kulturowych. Podkreśla się braki tych młodych ludzi w kompetencjach intelektualnych, niewysoki poziom oczytania i rozumienia lektur - szczególnie rozumienia strukturalnego i interpretacyjnego wątłe zasoby werbalne, niedobory w obszarze umiejętności i technik uczenia się oraz - nierzadko - słabą motywację poznawczą, a także braki w obyciu akademickim. Wymownie nazwał ten stan Maciej Gdula, używając określenia „smutny boom edukacyjny” dla oznaczenia dobra, które nie zawsze cieszyło (Gdula 2013).

W tej krytyce, ciągle żywej, wyraziście rysuje się zjawisko oburzenia. Wywołuje je nie tylko fakt niemałego udziału szkolnictwa niepublicznego w systemie oświatowym (co oznacza nie tylko dostęp do edukacji na poziomie wyższym, ale również wzrost nierówności edukacyjnych w przypadkach finansowej elitaryzacji części owych szkół). Ale również przeświadczenie, że masowość drastycznie obniża poziom kształcenia. Wszystko to mobilizuje do przyjrzenia się temu zjawisku oburzenia.

\section{Oburzenie jako element krytyki edukacji umasowionej}

Zasygnalizowana problematyka jest obecna w literaturze humanistycznej. Jednak wiedzę w niej zawartą przesłania potoczne rozumienie oburzenia - czyli stanu objawiającego się sprzeciwem, gniewem i irytacją podmiotów wywołanymi przez występujące w otoczeniu fakty i zachowania uznawane za nieodpowiednie w danych okolicznościach. Tak rozumiane oburzenie może dotyczyć zarówno złej, jak i dobrej sprawy. Tutaj natomiast idzie o ustosunkowanie się do fenomenu wzrostu liczby wyższych uczelni niepublicznych z możliwym zaniżaniem poziomu nauczania. Teoretyczny kontekst tak rozumianego oburzenia stanowi problematyka psychologii emocji ujemnych. Ich występowanie odbija się na jakości relacji personelu akademickiego i studentów, którzy bywają odbierani przez wykładowców ambiwalentnie - ich stosunek waha się między niechęcią i zniecierpliwieniem a poprawną życzliwością.

Bardziej pogłębione są filozoficzne interpretacje oburzenia. Znaleźć je można w tekstach Arystotelesa, Kartezjusza, Spinozy czy Nietzschego (zob. Misiuna 1993). Oburzenie wiąże się w nich z moralną oceną ludzi, którzy reprezentują wartości 
inne od naszych. W przypadku odniesienia fenomenu oburzenia do oceny umasowionego szkolnictwa wyższego dotyczy ono różnic w wartościowaniu wykształcenia przez tradycyjnych akademików i studentów-nuworyszy. Pierwsi widzą w kształceniu autoteliczną wartość elitarną, osiąganą przez tych, którzy przyswoją uogólnioną wiedzę dziedzinową, sprawność umysłową, zdolność do orientowania się w rzeczywistości, interpretowania jej, ciągłego intelektualnego rozwijania się z pielęgnowaniem etosu poznawania - co jest ukoronowane prestiżowym dyplomem. Natomiast drudzy traktują kształcenie instrumentalnie, jako narzędzie lepszego urządzenia się w życiu, a dyplom nazywają niekiedy „papierkiem” przydatnym do realizacji własnych celów. Oburzenie akademików na masowe instytucje kształcące i ich studentów dotyczy właśnie rozbieżności zasygnalizowanych wartości.

Jakkolwiek by je ustalono, kształcenie polega na wprowadzaniu ludzi na poziom intelektualny o określonym standardzie. Realizację takich zamierzeń można rozpatrywać jako szansę bądź jako trudność tym większą, im większa jest rozbieżność między punktem startowym a stanem zamierzonym. Rozwiązanie problemu wymaga zwarcia luki koniecznej dla przebycia odległości między intencjami a kompetencjami uczących się podmiotów. Idzie więc o przechodzenie od możliwości do rzeczywistości.

Szerzej rzecz ujmując, powiedzmy, że chodzi o pytanie - jak tworzyć nową rzeczywistość społeczną z udziałem ludzi ukształtowanych w realiach odchodzących w przeszłość, którą zamierza się przeobrażać ich siłami? Odniesienie tego zagadnienia do sfery edukacyjnej oznacza przechodzenie od stanu zaniedbań i braków kształceniowych do stanu realizowania przeciwstawnych zamierzeń.

W tym miejscu pojawia się pytanie o wykształcalność jako możliwość osiągnięcia wykształcenia przez jednostki. Jest to zagadnienie ważne przy ustalaniu granic dostępu do poszczególnych szczebli systemów oświatowych. Powściągliwość w ustalaniu takich granic uzasadnia psychologiczna wiedza o plastyczności uczenia się i o czynnikach psychicznego rozwoju człowieka. Pomimo tych argumentów w sferze empirii pojawiają się pytania: kto może ukończyć szkołę średnią, kto nadaje się do studiowania na poziomie wyższym? Spór o wykształcalność i niewykształcalność trudno jest rozstrzygać drogą badań instytucjonalnych i przy stosowaniu standardowych metod. Dlatego warto zwrócić się ku projektowi niestandardowemu, a z takim wystąpił w 1987 roku francuski badacz Jacques Rancière. W książce zatytułowanej prowokacyjnie „Nauczyciel ignorant” przedstawił on „pięć lekcji o emancypacji intelektualnej" (Rancière 1991). Zagadnienie emancypacji intelektualnej odniosłam do problemu ludzi kształcących się w dzisiejszych niepublicznych szkołach wyższych, którzy jednak są do tego „nieprzygotowani”, chociaż mają formalne podstawy, a także określone aspiracje kształceniowe.

Moje spotkanie z przywołaną publikacją okazało się znaczące dla zinterpretowania własnych akademickich prób dydaktycznych, osnutych wokół nazwanego problemu, jakie prowadziłam w dwóch wyższych szkołach niepublicznych zlokalizowanych na terenie Warmii i Mazur w latach 2005-2017. 
Uprawiałam je we współpracy ze studentami jako środowiskowymi nuworyszami kształcenia się na poziomie wyższym. Początkowo nie miałam zamiaru teoretyzować, z czasem jednak z chęcią poprowadziłam refleksję nad intrygującymi sytuacjami, w których uczestniczyłam. Ujmując rzecz w aspekcie biograficznym - doświadczenia te stanowiły szczególnie ważne wydarzenia mojej zawodowej aktywności jako teoretyka kształcenia.

\section{„Ignorant teacher” Rancière’a jako możliwa postać zmiany edukacyjnej}

Główna myśl Rancière’a dotyczy przyjęcia przez niego nieprawdziwego, kontrfaktycznego, wręcz naiwnego założenia o równych poziomach inteligencji ludzi (a więc i uczniów), wyznaczających ich potencjały poznawcze (Rancière 1991: 18).

To założenie autor przekształcił w utopijną hipotezę poddawaną następnie próbie niepozytywistycznej, czyli bez wykonywania klasycznej weryfikacji/falsyfikacji. Uczynił z niej natomiast podstawę pracy pedagogicznej, wiodącej ku czynieniu owych założeń prawdziwymi. Nie prowadzono w tej pracy pomiaru samej uczniowskiej inteligencji, nie izolowano jej, lecz akcentowano to, co udało się osiągnąć w obszarze uczniowskiego poznawania (Rancière 1991: 46). Przyświecała temu myśl, że inteligencje - jako potencjały - drzemią w nas wszystkich, trzeba więc robić coś, co je pobudzi.

Tytułowa ignorancja nauczyciela nie oznacza u Rancière’a stanu pedagoga wynikającego z jego nieuctwa, braku wiedzy bądź nieświadomości. Dotyczy natomiast niebrania pod uwagę uczniowskich braków, które mogą być hamulcem w skutecznym nauczaniu i uczeniu się.

Autor pomysłu dokonuje więc dopełnienia braków uczniów - obok negatywnej postaci niedouczonego ucznia ignoranta, utrwalonej w tradycyjnej dydaktyce, lokuje pozytywną postać nauczyciela ignoranta. Pomija on braki swoich uczniów, które są barierą w czynieniu przez nich postępów poznawczych. W hasłach ,ignorant dydaktyczny” i „równość inteligencji” wyróżniam dwie warstwy. Jedna dotyczy równości ignorancji nauczyciela i ucznia, gdzie nauczyciel w kontakcie z uczniem niejako „wycofuje” swoją inteligencję. Warstwa druga dotyczy założenia o równości inteligencji różnych uczniów, pracujących z tym samym nauczycielem. Podstawą przyjętej interpretacji czynię to, że Rancière wypowiada się o inteligencji ludzkiej bez dzielenia osób na nauczających i nauczanych. Wokół powyższych tez osnuta jest poniższa próba dotycząca interpretacji mojej roboty dydaktycznej.

Gdyby odnieść Rancière’owski pomysł założenia równości inteligencji do teoretyzowania ignorancji - widząc w niej możliwy stan pierwotny, wrodzoną niewiedzę, wiedzę nienabytą, niepełną lub wykrzywioną, zapomnianą lub wypartą, wiedzę nieaktualną, selektywny wybór informacji i interpretacji, konstrukt bierny lub aktywny czy chwyt strategiczny (Kwieciński 2019: 138) - to można by uznać go za „strategiczną koncepcję" potraktowania kwestii nauczania i uczenia się. 


\section{Nauczycielska robota własna wobec inspiracji Rancière’owskich; teren, ludzie, zamierzenia akademickie, etapy pracy i epizody egzemplifikacyjne, komentarze i wyniki}

Przez wprowadzenie do śródtytułu słowa „robota” sygnalizuję specyfikę pracy wykonywanej przez niestacjonarnych studentów wybranych niepublicznych uczelni i ich nauczycielki. Nawiązując do dokonanego przez Hannah Arendt rozróżnienia na "pracę" - jako codzienny trud, „wytwarzanie”, będące produkowaniem rzeczy, i „działanie” - jako rozpoczynanie czegoś znaczącego dla dobra wspólnego (Arendt 2000), naszą uczelnianą „robotę” odbierałam jako aktywność jeszcze inną. Miała ona cechę intensywnego, twardego, podstawowego wysiłku zmierzającego do nadrabiania braków, uprawianego w okolicznościach niejako wymuszających takie postępowanie. Była to ciężka praca: wykonywana w napięciu, w stanie zmęczenia udziałem w skomasowanych zajęciach dydaktycznych, łączonych z obowiązkami zawodowymi studentów i ich rolami rodzinnymi, podporządkowana wymagającej uczelnianej organizacji i zewnętrznym naciskom pracodawców oraz rodzin studentów. Pracę tę dodatkowo utrudniała nieumiejętność znalezienia się młodzieży w pozycji akademickiej, ich borykanie się z przezwyciężaniem meandrów własnego studiowania oraz z określaniem jego sensów, w którym ścierały się przekonania o przewadze znaczenia formalnych aspektów postępów akademickich albo ich warstwy merytorycznej. Przechodzę do opisu elementów i etapów tak wykonywanej roboty.

\section{Teren}

Dla charakterystyki miejsca wykonanej akcji dydaktycznej, a takie kontekstowe osadzenia uznaję za znaczące dla rozpatrywania problemów edukacyjnych, zasygnalizowałam cztery składowe elementy wiedzy o:

- historycznej przeszłości Warmii i Mazur oraz etnicznej specyfice mieszkańców, dostępnej w literaturze przedmiotu; obszerna bibliografia Warmii i Mazur od 1945 roku jest zgromadzona w Wojewódzkiej Bibliotece Publicznej w Olsztynie;

- dramatycznej zmianie, która nastąpiła tutaj po II wojnie światowej, kiedy na skutek decyzji politycznych doszło do przymusowego, zakrojonego na szeroką skalę, wysiedleńczo-przesiedleńczego ruchu ludnościowego, który spowodował erozję społeczności lokalnych;

- przemieszaniu kultur, zjawisku anomii oraz o przeobrażeniach charakteru gospodarki przez zamienienie dawnych majątków ziemskich w państwowe gospodarstwa rolne, których środowiska kształtowały mentalność w trybie podporządkowania, bezinicjatywności, samousprawiedliwień, z normą jako przymusem zewnętrznym, gdzie ludzie żyli w złych warunkach, wręcz w ubóstwie materialnym i kulturowym; 
- obecnej jakości życia i perspektywach mieszkańców tego terenu, peryferyjnego w skali kraju, z odniesieniem do społecznego oraz kulturowo-przyrodniczego zakorzenienia ludzi.

Zakładając orientację czytelnika w wypunktowanych zagadnieniach przeszłości, zarysuję tylko stan teraźniejszy, który odniosę do szerszej dyskusji nad rozwojowymi perspektywami tych regionów. Jest to kwestia osadzona w teoretycznej problematyce alternatywnych relacji rozwojowych rdzenia i peryferii, gdzie przyjmuje się, że albo doinwestowane centra promieniują rozwojowo na otaczającą je prowincję, albo że owa prowincja rozwija się według inicjatyw lokalnych, wnosząc swój wkład w rozwój całości (Grosse 2002; Springer 2016). Ostatnio podkreśla się znaczenie trzeciej tezy - glokalizacyjnej, zgodnie z którą regiony są kształtowane przez przepływy dwukierunkowe. Przyjmując - być może nadmiernie optymistycznie - tę ostatnią tezę, popatrzmy, jak dzisiejsze przepływy kształtują ziemie warmińsko-mazurskie.

W poszukiwaniach odpowiedzi na to pytanie warto sięgnąć do raportu „Kultura pod chmurnym niebem". Dynamiczna diagnoza stanu kultury województwa warmińsko-mazurskiego. Raport i rekomendacje praktyczne opracowanego przez zespół naukowy pod kierunkiem Barbary Fatygi (2014). Główne wnioski autorów $\mathrm{z}$ raportu są następujące:

- tereny te zostały określone jako obszar „podwójnej peryferyjności”, gdyż są usytuowane na peryferiach półperyferyjnych - zarówno dawnych, jak i dzisiejszych bytów politycznych. Do dziś są one raczej przedmiotem niż podmiotem historii, gdyż od zakończenia II wojny nie osiągnęły - jak się wydaje - stanu zakorzenienia. W raporcie tę sytuację określono mianem „klątwy wiecznego początku". Wiąże się ona również z chwiejnością tutejszych tożsamości - zarówno zbiorowych, jak i indywidualnych (Fatyga et al. 2014: 141). Oznacza to, że tutejsi ludzie zmagają się z traumą ciążąca nad nimi i ich ziemią - jak to powiedział publicysta Erwin Kruk, dźwigają na plecach "garbate mazurskie brzemię" a także, że zwracają się ku przeszłości, ku powojennym zmianom etnicznym i doświadczeniom gospodarczym, uznając je za znaczące dla kształtowania norm i wartości postmigracyjnych społeczności. Pogłębienie powyższej problematyki, osadzone w kwestii wiekowej kulturowej lokalizacji Polski między Wschodem a Zachodem, można znaleźć w tekstach wykraczających poza analizy uwarunkowań lokalnych (zob. Sowa 2011);

- przyroda i turystyka, $\mathrm{z}$ akcentem na turystyczne eventy, odbierane potocznie jako lokalne atuty rozwojowe, zewnętrznie wspomagane finansowo, uznano w raporcie za „ślepą uliczkę dla Warmii i Mazur”. Przeprowadzone analizy jednocześnie doprowadziły autorów do konstatacji, że „najcenniejszymi zasobami Warmii i Mazur nie jest natura czy dziedzictwo kulturowe, ale ludzie kultury i drzemiące potencjały społeczności lokalnej" (Fatyga et al. 2014: 142). Potencjały te mogą się jednak różnie realizować. Edwin Bendyk widzi je w możliwej adaptacji, konserwacji bądź kolonizacji (jako zależności od turystów) przy powiązaniu ich realizacji z językiem mówienia o rozwoju. Tego zaś nie należy 
utożsamiać ze wzrostem gospodarczym o strukturze pionowej, organizowanej wokół wysokości PKB, stanowiącym tylko środek do celu. Należy go potraktować jako poziomą zdolność regionu do odtwarzania zasobów ekonomicznych, demograficznych, symbolicznych, środowiskowych, bez konieczności interwencji z zewnątrz. Pierwotnie ważna jest więc - zdaniem autorów - zdolność warmińsko-mazurskiej społeczności do „mobilizacji i samodzielnego definiowania rozwoju” (Bendyk 2014: 156).

W świetle konstatacji o wadze koncepcyjnej samodzielności mieszkańców regionu podjęty tutaj temat edukacyjny odnoszący się do emancypacyjnych szans studentów, którzy rozpoczynają naukę w niepublicznych szkołach wyższych w ramach boomu edukacyjnego, jawi się jako znaczący, jeśli hipotetycznie powiążemy go z budowaniem podmiotowego nastawienia tej młodzieży do siebie i do swojego regionu, sprzyjającego emancypacyjnemu wyzwalaniu się z ograniczeń przeszłości i współokreślaniu kierunków rozwoju.

Dla jego kształtowania w ludziach potrzebne jest - co podnosiła Ewa Woydyło-Osiatyńska w rozważaniach o relacji centrum i peryferii - „indywidualne, osobiste dostrzeżenie własnych skrzydeł, nie tylko korzeni”, oznaczające konieczność zmniejszania uwagi skierowanej ku sprawom przeszłości regionu, a zwrócenie jej ku teraźniejszości (Woydyło- Osiatyńska 2010). Pułapka tkwi w tym, że w rozplątywaniu owych korzeni można uwięznąć i przesłonić nastawienia aktualne i przyszłościowe. W zarysowanej perspektywie ważne jest pytanie, jak ziemia warmińsko-mazurska jest osadzana świadomościowo przez samych jej mieszkańców w rozszczepieniu między własnym „dziś” (z emancypacyjnymi osiągnięciami ostatnich dziesięcioleci) a swoim „wczoraj” (ze skutkami powojennych zmian etnicznych i gospodarczych i wyrastającą na tym gruncie mentalnością). Jestem zdania, że nastawienia te mogą być - pośrednio - znaczące dla aktualnych stylów poznawczych studiującej młodzieży (która pokoleniowo przyswaja sobie doświadczenia regionu $\mathrm{z}$ akcentem położonym na przeszłość bądź przyszłość) przejawiających się w sposobach uprawiania własnego kształcenia jako aktywności adaptacyjnej bądź emancypacyjnej.

Podsumowując, dla charakterystyki terenu, na którym pracowałam, z potraktowaniem Rancière’owskiej postaci nauczyciela ignoranta jako modelowej dla późniejszej interpretacji działań własnych i studenckich, niemałe, chociaż pośrednie, wydawało się uwikłanie teraźniejszości w przeszłość. Czyniło to kwestie emancypacyjne szczególnie znaczącymi.

W tej sytuacji reagowanie oburzeniem na stan zastany, co bodaj jest udziałem niemałej części akademików uczestniczących w „ludowych” procesach edukacyjnych, można uznać za hamulec i jałowe wydatkowanie energii. A tę należałoby kierować na zwielokrotnione i dodatkowo zenergetyzowane pobudzanie aktywności podmiotów do podejmowania wysiłków na rzecz zmiany związanej z wyzwalaniem się z zaprzeszłych doświadczeń. 


\section{Ludzie}

Powyższy szkic charakterystyki regionu stanowi wstępne źródło sygnałów o zamieszkujących go ludziach. Historia nie poskąpiła im trudnych wydarzeń, a układy polityczne nie stanowiły sił wspomagających ich wydobywanie się z dziejowych komplikacji. Pewien odcień tutejszych klimatów pozwala odczuć utwór Bajka (1994) autorstwa Erwina Kruka, lokalnego poety i publicysty.
Żyli w krainie naiwnej,
A tak pięknej i niecodziennej,
Że gdy pewnego razu
Goście z hałasem weszli do ich domów,
To widokami byli wprost urzeczeni.
Tak im się okolice spodobały,
Że dla dawnych gospodarzy
Wkrótce nie stało już miejsca.
I ci, jeśli przeżyli powitanie
I wracali $\mathrm{z}$ rozproszenia
Do dawnych zagród,
Aby nie szpecili urody krajobrazów
Wypychani byli za próg,
Za bramy i miedze coraz dalsze.
Dopiero teraz
Miało się okazać,
Że mimo potulnego odchodzenia
Ciągną się za nimi słowa skargi.
Bo choć wszystko w pośpiechu zostawili,
To jednak piękno,
Które przydawało blasku tej krainie,
Ukryli w jakichś ciemnych jamach i norach,
A ślady zatarli.

Przechodząc nad wydarzeniami powojennymi, zatrzymajmy się na przełomie 1989 roku. Tutejszą ludność dotknęło wtedy bardzo wysokie bezrobocie, szczególnie popegeerowskie. W 2004 roku osiągnęło ono tutaj najwyższy stopień w Polsce $29,6 \%$. Najpierw odziedziczona słaba infrastruktura produkcyjna, później powojenne przemieszczenia ludności w warunkach chaosu wartości, które mogły zmieniać postawy jednostek wobec norm społecznych oraz prawnych (Czapka 2006: 71-72), następnie demokratyczna i wolnorynkowa zmiana ustrojowa $z$ jej gospodarczymi konsekwencjami - wszystkie te czynniki tworzyły sytuację społeczną, w której wykrystalizowały się co najmniej dwie tendencje.

Jedna z nich dotyczyła podstawowej potrzeby ludzi - poprawiania jakości swojego życia, co słusznie łączono z dostrzeganiem roli wykształcenia i aspiracjami do podnoszenia jego poziomu (Kawczyńska-Butrym 2006b: 225). Tyle że wykształcenie interpretowano wąsko pragmatycznie - jako drogę do zdobywania lepszej pracy i wyższych zarobków. 
Tendencja druga odnosiła się do realizacji tych aspiracji. Oddają je statystyki dotyczące liczby studentów w województwie warmińsko-mazurskim oraz dane o relacji tej liczby do sumy mieszkańców. Otóż w roku akademickim 2017/18, na tle stanu szesnastu województw, liczba studentów województwa warmińsko-mazurskiego plasowała się na czwartym miejscu dolnych pozycji rankingu - przed lubuskim, opolskim i świętokrzyskim. Natomiast dane z 2013 roku, dotyczące relacji liczby studentów do populacji mieszkańców województwa, mówią o trzecim miejscu od końca tego obszaru, za nim zaś stoją województwa lubuskie i podkarpackie. Powyższe zestawienia traktuję jako wskaźniki niskich wyników oświatowych, nieadekwatnych do aspiracji kształceniowych ludzi regionu.

Źródeł tego stanu można dopatrywać się w ukształtowanym w danych warunkach stylu edukacyjnym klasy ludowej. Określenia tego używam w znaczeniu socjologicznym (zob. Bourdieu, Sadura, Gdula), jako określenie warstwy, z której wywodziło się prawdopodobnie wielu współpracujących ze mną studentów. Styl ten opisał Przemysław Sadura na podstawie wywiadów przeprowadzonych z robotnikami rolnymi i pracownikami fizycznymi w Polsce oraz z ludźmi klasy średniej i wyższej w województwie warmińsko-mazurskim. Potwierdziły one znaną już myśl, że szkoła jako instytucja oświatowa stosująca nacisk, abstrakcyjne programy nauczania oraz dyscyplinę uczenia się opartą na tradycyjnych wartościach klasy średniej nie pociągała dzieci z klasy ludowej (Sadura 2015: 39).

Nie wiemy jednak, czy ludzie klasy ludowej tego terenu nie potrafili znaleźć się w szkole tak ukształtowanej, czy też nie mieli nawet okazji się z nią zetknąć i skorzystać z szans rozwojowych, jakie dawała. Badania nad młodzieżą województwa warmińsko-mazurskiego ujawniły bowiem negatywne opinie samych młodych o jakości szkół, do których uczęszczali - z niskim poziomem nauczania, słabym zawodowym przygotowaniem pedagogów, lichym materialnym wyposażeniem oraz niskim poziomem zarządzania (Kawczyńska-Butrym 2006b: 223-224). Dane te dopełniają wyniki Elżbiety Tarkowskiej dotyczące niekorzystnych warunków szkolno-rozwojowych młodzieży z terenów popegeerowskich (Tarkowska, Korzeniowska 2002) oraz wyniki badań nad nauczycielami Polski północno-wschodniej przeprowadzone przez Aleksandra Nalaskowskiego (1998).

W takich oto okolicznościach spotkała się nauczycielka - z autocharakterystyką dosyć tradycyjnego ideowca edukacyjnego, deklarująca egalitaryzm, ale doświadczana w relatywnie elitarnym środowisku akademickim - a następnie wykładowczyni niepublicznych szkół wyższych na terenie warmińsko-mazurskim ze studentami pragmatykami. Niełatwo było im osiągnąć wzajemne porozumienie. Mówiąc wprost - bez obustronnego oburzenia obejść się nie mogło. Profesorka, mająca określone wyobrażenia o społecznych funkcjach i pożądanym poziomie wyższego wykształcenia, stawiała studentom standardowe wymagania uniwersyteckie. Oburzała się także, gdy ci nie mogli im sprostać. Studentów natomiast, którzy w uzyskaniu wykształcenia widzieli perspektywę wejścia na lepszą drogę indywidualnej 
egzystencji i musieli opłacać czesne ${ }^{1}$, oburzała nauczycielka, która - nie doceniając, ich zdaniem, owych wysiłków, ryzyka i nie znając realnego życia - wystawiała im niskie oceny, a - nierzadko - nie zaliczała przedmiotów. W odpowiedzi na to uczniowie stawiali opór - najczęściej bierny, a więc nietwórczy, nierozwojowy (Bilińska-Suchanek 2000: 73), co nie rozwiązywało trudnej sytuacji. Nauczycielka była zdeterminowana, żeby zrealizować akademicki program kształcenia. Niemała część studentów natomiast była nastawiona na wymuszenie ustępstwa argumentem, że w szkole niepublicznej stawianie wymagań jest niewłaściwe, gdyż tutejszym atutem jest opłacanie czesnego, a oni ten warunek spełniają. Ten wątek naszych rozmów, początkowo gorący, z czasem ograniczał się, aż zupełnie wygasł. Sądzę, że łączyło się to ze zmianą znaczenia, jakie nadawano fenomenowi „wymagań akademickich”.

Ale jak pierwotnie można było wyjść $\mathrm{z}$ sytuacji, w której nauczycielskie ustępstwa skutkowałyby negatywnym wynikiem kształceniowym, a ich brak tworzyłby układ patowy, paraliżujący pracę? Do tego napięcia ważny wkład wniosła studentka uczestniczka wydarzeń, która potrafiła wniknąć w ich specyfikę i wyobrazić sobie pożądaną perspektywę. Jej głos przedstawię w dalszej części tekstu jako „epizod I”.

\section{Zamierzenia nauczyciela akademickiego}

Programy prowadzonych przeze mnie przedmiotów - a były to metodologia badań społecznych i twórcze zachowania ludzi - obejmowały odpowiednie treści oraz zamysł takiego kształtowania studentów, w którym nie eksponowano transmisji wiedzy, chociaż zdecydowanie przywiązywano wagę do jej opanowania. Towarzyszyło temu akcentowanie roli czytania lektur, podejmowania samodzielnych studenckich prób myślowych odnoszonych do poznanych tekstów, różnorodnego $\mathrm{w}$ formach przetwarzania materiałów dostarczanych przez samych studentów oraz prowadzenia przez nich małych prób badawczych, a także analizowanie i porównanie uzyskiwanych wyników, interpretacyjne odnoszenie poznawanych teorii do wydarzeń i doświadczeń z życia środowiskowego i zawodowego młodzieży. Zajęcia dopełniały skromne projekty plastyczne, inscenizacyjne, projekcje filmowe, ilustrowanie tematów licznymi przykładami empirycznymi, także fragmentami literatury, niekiedy poezji (ulubionym utworem studentów okazała się Cebula Wisławy Szymborskiej), a także wykonywanie przez wykładowcę roboczych szkiców kredą na tablicy, dostosowanych do sytuacyjnych potrzeb słuchaczy, programowo bez używania prezentacji multimedialnych.

Tę atmosferę przesycał klimat stawiania studentom wyraźnie określonych wymagań, okazywania dbałości o zachowanie konstruktywnego elementu zajęć - zarówno treściowego, jak i organizacyjnego - dotrzymywanie terminowości zobowiązań,

\footnotetext{
Aby je opłacić, często podejmowali się ciężkiej pracy, nawet związanej z przemytem - zajęcia dosyć powszechnego na terenach przygranicznych (Czapka 2006: 74). Czasem musieli korzystać też z pomocy rodzin, a nawet skromnych emerytur dziadków.
} 
systematyczne omawianie i komentowanie wytworów słuchaczy. W toku wszystkich prowadzonych prac przestrzegano zasady powtarzania tego, co okazywało się niejasne, oraz podkreślano uzyskiwanie przez uczących się rozumiejącego wglądu w poznawaną problematykę. Dotoczyło to również prac egzaminacyjnych, kiedy błędne wypowiedzi studentów były zarówno przedmiotem oceniania (bynajmniej nie zliberalizowanego, gdyż takie oznaczałoby lekceważenie studentów), jak i wspólnego, prowadzonego w formie długich poprawkowych rozmów, dyskutowania i wyjaśniania zagadnień programowych sprawiających szczególne trudności.

$\mathrm{Na}$ robotę przeprowadzaną przez nauczycielkę składały się panowanie nad własnym, odbieranym już jako jałowe, oburzeniem na „niemożności” studentów i przyjęcie - bardziej intuicyjnego niż wyartykułowanego - założenia o konieczności trwania przy nauczaniu ludzi wbrew ich niedoborom, z możliwie pozytywnym nastawieniem i położeniem nacisku na niwelowanie zaniedbań rozwojowych, które ich dotknęły. To nastawienie zinterpretowałam - po czasie - jako bliskie Rancière’owskiej koncepcji. Opiera się ona założeniu o równych poziomach inteligencji wyznaczających potencjały poznawcze. Zostało ono następnie przekształcone w hipotezę weryfikowaną przez działania, które czyniły owe założenie prawdziwym (Rancière 1991: 101).

Charakteryzując nauczycielskie zamierzenia, trzeba powiedzieć, że zastosowana koncepcja pracy nie była wewnętrznie spójna. Stanowiła ona bowiem kompilację lub bardziej zderzenie dwóch paradygmatów dydaktycznych, ponieważ obydwa wydawały się przydatne w realnej sytuacji prowadzonego działania. Były to elementy dydaktyki tradycyjnej - z wątkiem podającym, stawianiem zadań, wymaganiem adaptacji studenta do akademickich metod, $\mathrm{z}$ akcentem na pracę z tekstem, rozważaniem znaczeń pojęć, prowadzeniem wywodów - łączone z zasobami dydaktyki progresywnej - z jej elementami liberalnymi, działaniowo-konstruktywnymi, stwarzającymi studiującym przestrzenie do zachowań samodzielnych i twórczych.

Ta dwoistość była też wymuszona przez zderzenie reprezentantów dwóch światów uczestniczących w procesie edukacyjnym: „ludowego” ucznia z „elitarnym” uniwersyteckim akademikiem. Każda strona miała swoją wiedzę, doświadczenia, racje i wizje. Każda dostrzegała napięcia w spotkaniu z drugą stroną, odczuwała potrzebę wniesienia zmiany w zachodzące relacje, ale nie dysponowała pomysłem na nią. Co osiągnęliśmy? Wchodząc poniekąd w przestrzeń tworzenia „trzeciej drogi dydaktycznej”, nie zdołaliśmy zbudować jej do końca. Chociaż - być może - osiągnęliśmy to, co można uznać za przyczynek do postawionej kwestii, a mianowicie - hodowaliśmy „kiełki zmiany emancypacyjnej”, o których napiszę w zakończeniu tekstu.

W szerszym planie rzecz cała odnosi się do relacji paradygmatów i pytania - na ile w pracy dydaktycznej stosowanie „czystych” rozwiązań paradygmatycznych jest pożądane, a na ile możliwe i pożyteczne bywa ich miksowanie przez osadzanie we wspólnym mianowniku realności życia, sprzyjające naruszaniu schematów i zaistnieniu warunków chaosowych? U podstaw tej uwagi leży przekonanie o wadze 
poszukiwania metod uprawiania edukacji umasowionej, ale nie sprymityzowanej, oraz wątpienie w proste przenoszenie metod pracy dydaktycznej z obszaru edukacji zelitaryzowanej na obszar edukacji otwierającej się na umasowienie. Nie oznacza to jednak, że tę drugą należy sprowadzać na poziom ludyczno-elementarny, zawierający w sobie etycznie problemtyczny element poniżania osób studiujących.

\section{Etapy pracy, epizody egzemplifikacyjne, komentarze}

W przeprowadzonej robocie edukacyjnej wyróżniam następujące etapy:

- etap spotkania - przesycony nastojem oburzenia;

- etap działań dydaktycznych - charakteryzujący się aktywnością chaosową;

- etap pożegnania - znaczony werbalizacją "kiełkowania emancypacyjnego”.

Scharakteryzuję je przez opisy pojawiających się z rzadka małych aktów dydaktycznych, określonych tutaj mianem „epizodów”. Odczytywałam je jako szczególnie nasycone merytorycznie, egzemplifikacyjne oznaki zwrotów rysujących się w naszej pracy, wskazujących na pojawianie się w niej nowych znaczeń. Dopatrywałam się w nich elementów emancypacyjnych stanowiących jakości szczególnie ważne dla ludzi i miejsc, w których studiowaliśmy. Każdy epizod jawił się jako fragment większego wydarzenia, rzecz - sama w sobie - małej wagi, ale taka, która mogła nieco naruszyć istniejący układ, a to stawało się potencjalnie znaczące dla konstytuowania się nowego porządku.

Pojęcia „emancypacja” nie wprowadzam w znaczeniu szerokim, jako relacji uniwersalności z partykularnością (Laclau 1996), lecz w sensie aplikacyjnym, z myślowymi odniesieniami do pracy Roberta Kwaśnicy (2007). Głównie jednak kładę akcent na pedagogikę emancypacyjną definiowaną jako ta, która jest realizowana „poprzez tworzenie warunków rozwoju, podmiotowego mówienia własnym głosem i świadomego uczestniczenia w zmienianiu siebie i swojego świata życia” (Czerepaniak-Walczak 2006: 60).

Przechodząc do opisu etapów pracy własnej, powiem, że nastroje towarzyszące wstępnym kontaktom studentów i nauczycielki akademickiej, określonym jako charakterystyczne dla „etapu spotkania”, obejmującego co najmniej pierwszy rok pracy, oddaje już ta część tekstu, którą poświęciłam charakterystyce fenomenu oburzenia, ponieważ właśnie takie wzajemne napięcia przepełniały wówczas relacje stron. Przy końcu tego początkowego okresu doszło jednak do małego, ale ważkiego wydarzenia, które - jak sadzę - było przebłyskiem zmieniania się sensu realizowanej roboty. 


\section{Epizod I - „Instruktorka”}

Po egzaminie pisemnym przeprowadzonym po pierwszym roku pracy, w którym uzyskano słabe wyniki, podeszła do mnie na uczelnianym korytarzu studentka i powiedziała: „Pani musi to wytrzymać”. Na moją prośbę objaśniła zdecydowanie, że powinnam pozostać przy moich zasadach i wymaganiach, wytrwale tłumaczyć tematy, nie zważając na niedobory młodzieży w umiejętnościach uczenia się i codziennych zachowaniach. „Nas nie miał kto tego nauczyć” - podsumowała, po czym odeszła i zniknęła wśród innych. Nigdy więcej jej nie zobaczyłam. Być może należała do studentów, których ogarnął uczelniany odsiew.

Emancypacyjne aspekty opisanego zachowania dostrzegam w zdolności wyzwolenia się słuchaczki pierwszego roku studiów stacjonarnych z tradycyjnej, podporządkowanej roli uczniowskiej i przyjęcia pozycji analityczki, która dokonała wglądu w sytuację i dostrzegła, że nauczycielskie działania, jeśli nawet są doraźnie niemiłe studentom, mogą mieć dla nich perspektywiczne znaczenia rozwojowe. Zdołała też oddalić tradycyjny respekt studentki przed wykładowczynią, wejść w rolę śmiałej „instruktorki”, która dokonała obserwacji, refleksji, uzasadnienia, własnej werbalizacji i przekazała - z zastosowaniem trybu rozkazującego - znaczącą wskazówkę do dalszej pracy profesorki. Nie było w niej miejsca na ustępstwa i ulgi dla żadnego z dwóch podmiotów dydaktycznych - każdy miał zrobić to, co należało. Student powinien uczyć się, natomiast nauczyciel akademicki musi wytrwać w wysiłku szczególnym - nie ustępować, wytrzymać obciążenia, a robić to w imię wspierania ludzi w trudnym wyzwalaniu się z ich życiowych zaległości.

Drugi etap pracy, widziany jako „etap działań dydaktycznych”, przebiegał w formule chaosowej, co nie znaczy chaotycznej. Odcinając się od potocznego znaczenia słów „chaos” i „, chaotyczny”, oznaczających zamęt, nieład, dezorganizację, zwróciłam się do filozoficznego znaczenia tego pojęcia. Oznacza ono zjawisko nieporządku, ale mające potencjał porządkujący strukturę na nowo (Tempczyk 1995: 147). Odnosi się do systemów złożonych i ich wrażliwości na małe zaburzenia parametrów, kiedy owe drobne zmiany modyfikują układy w sposób nieprzewidywalny, prowadząc do innej jakości. „Nierównowaga dobywa porządek z chaosu” na zasadzie, że „brak równowagi jest źródłem porządku" (Prigogine, Stengers 1990: 305).

Przyjęta koncepcja rozproszonych struktur dyssypatywnych dotyczy przypadkowego tworzenia się nowych struktur. Pokazuje to świat nie jako ściśle zdeterminowany, lecz także jako samoorganizujący się. Tak pomyślana teoria chaosu przezwycięża przepaść między prostotą a złożonością, opisując je w jednolity sposób, przekraczający stare podziały (Tempczyk 1995: 194).

O ile początkowo procesy chaosowe (jako przeciwstawne procesom zdeterminowanym) penetrowano w obszarze meteorologii, matematyki, fizyki, chemii, biologii, to obecnie uważa się, że występują one we wszystkich dziedzinach, co poszerzyło tematykę także o badania procesów społecznych. Pozwala to odnieść ją do zagadnienia kształcenia, które faktycznie realizuje się w układach niestabilnych. 
W jego tradycyjnych naświetleniach to instytucje oświatowe i nauczycieli uznawano za twórców porząaku dydaktycznego opartego na regularności, która - jakoby dawała podstawy do przewidywania biegu zdarzeń liniowych, z uzyskiwaniem odpowiednich wyników nauczania. Natomiast przyjęcie teorii chaosu pozwala ujmować procesy kształcenia przez pryzmat uwzględnienia także roli studentów. Wnoszą oni elementy zderzenia wielości, której nosicielami są różne czynniki przygodne (Laclau 1996): jako ludzie, sytuacje i wydarzenia, które mogą być źródłami małych zaburzeń parametrycznych. Ich dynamika tworzy drobne zmiany stanowiące impulsy rozwojowe, znaczące także w sferze kształceniowej (Rutkowiak 1996). Ten etap naszej pracy zilustruję opisem kilku epizodów dydaktycznych.

\section{Epizod II - „Mechanik samochodowy”}

Powtarzana kilkakrotnie próba zaliczenia przedmiotu o nazwie metodologia badań pedagogicznych kończyła się niepowodzeniami młodego człowieka - bezrobotnego mechanika samochodowego, który postanowił skorzystać z „okazji” utraty pracy, aby podjąć studia pedagogiczne i przekwalifikować się na zawód humanistyczny, bliski jego rzeczywistym zainteresowaniom. Wbrew dotychczasowym niepowodzeniom ostatnie, rozstrzygające zaliczeniowe spotkanie z wykładowcą pokazało, że student referuje zagadnienia płynnie i ze zrozumieniem. Na pytanie, jak doszło do tej zmiany, wyjaśnił, że w toku uczenia się dostrzegł analogię strukturalną między budową i działaniem silnika samochodowego ze współdziałaniem podzespołów (co znał ze swojego pierwszego zawodu) a układem badania w paradygmacie pozytywistycznym. Student przesunął wówczas akcent $\mathrm{z}$ mechanicznego zapamiętywania opisów poszczególnych etapów takiego badania na ich funkcjonalne powiązania, co pozwoliło mu ogarnąć sens całego postępowania badawczego. „Ja się w to wmyśliłem" - powiedział, zapewniając wykładowcę, że udało mu się uchwycić istotę rzeczy, o której mówiliśmy.

W tym epizodzie dostrzegam emancypacyjny wysiłek studenta polegający na samodzielnej zmianie we własnym uczeniu się. Wyzwolił się on z maniery zapamiętywania i odtwarzania treści bez zastanawiania się nad ich znaczeniami - co obserwowałam jako styl rozpowszechniony wśród młodzieży - i zaczął wnikać w ich sensy, co celnie wyraził neologizmem „wmyśliłem się".

\section{Epizod III - „Wymiana drapieżnika”}

Ćwiczenie kończące zajęcia z twórczego zachowania ludzi polegało na przygotowaniu i przedstawieniu przez ich uczestników inscenizacji znanej bajki. Studenci mieli w tym celu wykorzystać tylko przedmioty dostępne w standardowej sali wykładowej. Jedna z grup, prezentująca Czerwonego Kapturka, do odegrania roli 
wilka wybrała swojego kolegę, który w odpowiednim momencie dramatu wyszedł na scenę bez żadnego „kostiumu”, w codziennym ubraniu, z plecakiem. Oznajmił on widzom, że wprawdzie w lesie kiedyś grasował groźny wilk, ale ostatnio pojawiła się niebezpieczna puma, która zaatakowała babcię Kapturka. W tej chwili ustawił się do widzów tak, że mogliśmy odczytać firmową formę graficzną z napisem „Puma” na jego plecaku. Tak oto w klasycznej bajce nastąpiła wymiana drapieżnika.

Wyzwolenie się z reproduktywnego standardu w działaniu studenta polegało tutaj na zdekonstruowaniu treści bajki, przejściu od konkretu do abstrakcyjnej umowności, dokonaniu skrótu myślowego, wyeksponowaniu roli języka oraz pomysłowej aplikacji tych operacji do osiągnięcia zamierzeń parateatralnych. Emancypacyjny wydźwięk przywołanego wydarzenia dydaktycznego widzę w odejściu studenta od rozwiązań schematycznych (do których wielu słuchaczy się przystosowuje), w jego odwadze wprowadzenia własnego pomysłu, oderwania od rozwiązania naturalistycznego, zastosowanego w innych grupach, i zastąpienia go rozwiązaniem symboliczno-werbalnym, stawiającym przed widzem wymaganie interpretacyjnego odbioru tego dowcipnego chwytu, zrobionego w dobrym stylu.

\section{Epizod IV - „Anglista na wsi”}

Ten student, z którym pracowałam na poziomie magisterskim, ukończył licencjat z filologii angielskiej i był nauczycielem języka w małej wiejskiej szkole. Uczniowie, a także ich rodzice, nie mieli wysokich motywacji odnośnie do opanowywania odpowiednich umiejętności przez dzieci; używano argumentu, że przez życie można przejść bez znajomości języka obcego, więc wkładanie trudu w jego uczenie się jest zbyteczne. Student - nauczyciel języka, dodatkowo wykształcony muzycznie, szukał sposobu pobudzania motywacji, a jeszcze bardziej - ożywienia swojego środowiska. Zastosował następujący pomysł, który przedstawił na zajęciach.

Wieś, w której pracował, miała dobry chór kościelny, w którym chętnie uczestniczyli także uczniowie. Nauczyciel przetłumaczył słowa pieśni kościelnych na język angielski. Chór miał za zadanie odśpiewać je w tym języku. Dzieci dzięki temu ćwiczyły struktury i słownictwo języka obcego, zawarte w wykonywanych tekstach. Połączono ze sobą w ten sposób dwie intencje - religijną i dydaktyczną. Realizację pomysłu ułatwiło to, że nauczyciel współpracował z miejscowym kościołem, w którym był akompaniatorem organowym. Jego pomysł, później wariantowo rozwijany, zaowocował ożywieniem motywacji uczniów do uczenia się języka obcego i wychodzeniem poza swoje najbliższe otoczenie.

Emancypacyjne zachowanie studenta-nauczyciela dostrzegam w jego nastawieniu na uruchamianie uczniowskich motywacji wynikającym z niezgody na marazm środowiska oraz panujące $w$ nim konserwatywne przekonania, że wiejskiemu dziecku angielszczyzna nie jest potrzebna. Widzę je również w jego poszukiwaniach takiego pomysłu osiągania swojego zamierzenia, który - nawiązując do 
aktualnego kulturowego stanu otoczenia - sprzyjałby rozwojowemu przekształcaniu owego stanu w sposób, jaki byłby możliwy do przyjęcia dla jego uczestników. Były to poszukiwania ukierunkowane na otwieranie horyzontów, stwarzanie uczniom możliwości komunikacyjnych wykraczających poza lokalne ograniczenia, które mogą poszerzać ich kontakty i potencjały poznawcze.

\section{Epizod V - „Babcia baletnicy”}

Byłam zdziwiona, kiedy podczas przerwy między wykładami z metodologii, na których objaśniałam tezy Paula Feyerabenda, pewna studentka poprosiła o dodatkowe zinterpretowanie szczegółu z zakresu tej tematyki. Zapytałam o powód jej zainteresowania i dostałam odpowiedź. Okazało się, że o wyjaśnienia prosi babcia studentki. Dawno emerytowana nauczycielka, repatriowana po wojnie na tutejsze tereny. Kobieta ta dawniej była profesjonalną członkinią zespołu baletowego. Obecnie, z powodu komplikacji zdrowotnych, uczyła się zawodu pedagoga. Wypytywała swoją wnuczkę o interesujące wykłady, które ta odbierała podczas uczelnianych zajęć, i życzyła sobie powtarzania ich treści. W ten sposób studentka połączyła rolę słuchaczki z rolą rodzinnej wykładowczyni domowej.

Nieprosta figura, jaka się wytworzyła, polegała na tym, że emancypatorką studentki stała się jej babcia, która pomimo podeszłego wieku i trudnych warunków bytowych chciała wychodzić poza ograniczenia swojego życia, miała ciekawość świata, potrzebę uczenia się, chęć stawiania pytań i dociekania odpowiedzi. Taką postawą pośrednio naruszała mało entuzjastyczny stosunek do uczenia się, który studentka obserwowała wśród swoich rówieśników. Zarazem jednak to wnuczka-studentka, relacjonująca w domu uczelniane wykłady, niejako przekształciła swoją babcię w emancypatorkę, której zachowanie, tworzące rodzinną atmosferę eksploracyjną, mogło - zwrotnie - oddziaływać rozwojowo na wnuczkę. Natomiast nauczycielka akademicka była tutaj pomocnicą, nieintencjonalnie uruchamiającą środowiskowy ruch poznawczy, który rozchodził się tam nowymi, własnymi kręgami. Muszę wyznać, że nie wystarczyłoby mi wyobraźni, żeby zaplanować działania emancypacyjne, które powstały w opisanym epizodzie.

\section{Epizod VI - „Błazen grupowy”}

Bodaj każdy, kto ma dłuższe doświadczenie dydaktyczne, przeżył swoje spotkania i utrapienia $\mathrm{z}$ „błaznem klasowym”, figurą opisaną w swoim czasie przez Henry A. Giroux’a. Błazen studencki, którego spotkałam na własnej drodze, starał się jak mógł: komplikował zajęcia, sprawnie rozładowywał napięcia poznawcze, które próbowałam budować, jednym słowem - spełniał się w swojej roli. 
Nie byłam więc zdziwiona, kiedy w terminie zaliczania przedmiotu pojawił się przede mną i zapowiedział, że chciałby zadać mi pytanie, które jest tak ważne, że nie można go poprzedzić moim, skierowanym do studenta, co wynikało z procedury zaliczeniowej. Jego pytanie dotyczyło moich poglądów politycznych. Zobowiązałam się do udzielenia odpowiedzi pod warunkiem wyjaśnienia przyczyn, dla których student interesuje się tą sprawą.

Powody okazały się następujące: otóż studenci zauważyli, że ich wykładowcy różnią się między sobą sposobami naświetlenia wykładanej przez nich tematyki pedagogiczno-społecznej. Na podstawie tej obserwacji sformułowali hipotezę, że treści owych interpretacji wiążą się z poglądami politycznymi samych wykładowców. Hipotezę tę postanowili weryfikować na użytek własny i właśnie dlatego zostałam zaindagowana przez człowieka studenckiej grupy. Zgodnie z obietnicą przedstawiłam „błaznowi” w skrócie własne polityczne punkty widzenia, co on skwitował uwagą o weryfikacji ich hipotezy. Następnie przeszliśmy do zaliczania przedmiotu, kiedy już mogłam postawić swoje nauczycielskie pytania. Po zaliczeniu student wręczył mi książkę-pożyczkę o powiązaniach hitleryzmu i faszyzmu, czyli o tematyce odległej od naszych zajęć, którą niedawno odkrył dla samego siebie, i dołączył zalecenie zwerbalizowane następująco: „Pani musi to przeczytać”. Słowne formuły: „pani musi...” oraz „niech pani...” nie były dla mnie zaskakujące, gdyż nierzadko pojawiały się w naszych kontaktach, a ja już nauczyłam się dostrzegać w nich pozytywny wydźwięk mowy osób, którym na czymś zależy.

Powiem wprost, że „błazen” i ludzie z jego grupy studenckiej zaimponowali mi swoimi postawami wobec własnego uczenia się. Dostrzegłam w nim samodzielną emancypacyjną myślową robotę krytyczną: z odwagą wyjścia poza utarty tryb studiowania, z wprowadzeniem refleksji nad ukrytymi założeniami problematyki pedagogicznej oraz dydaktyki akademickiej, samodzielne dostrzeżenie i sformułowanie problemu, hipotezy, szukanie sposobów jej weryfikowania, okazanie wrażliwości na kontekstowe relacje polityki i edukacji, prowadzenie koleżeńskich dyskusji na ten temat i wreszcie wręczenie wykładowcy pożyczki lekturowej z wyrazistym kategorycznym nakazem, a nie z efemeryczną propozycją przeczytania jej.

Być może słuchacze tego rocznika nie mieli okazji poznać zagadnień polityczności i upolityczniania edukacji jako programowych, zatem- kiedy je dostrzegli w trybie obserwacji własnych - podjęli próby zrozumienia zjawiska. W ten sposób na miejscu wykładowcy zadającego pytania i lektury pojawił się student, który postawił sam sobie pytanie, zaproponował sposób sprawdzenia przypuszczenia, a dodatkowo zalecił wykładowcy czytanie tekstu według własnego wyboru i poczucia wagi. Kojarzę to $\mathrm{z}$ Rancière'owskim pojęciem intelektualnego wyemancypowania jako bycia „podróżnikiem umysłu”, kiedy człowiek myśli, kim jest, i jakie jest jego miejsce w społecznym porządku (Rancière 1991: 33).

W takich okolicznościach wspomniany „błazen” uzyskał w moich oczach nowy status i z utrapienia stał się nosicielem nadziei, że udaje się w tej robocie coś osiągać. 
Jak już sygnalizowałam, interpretację zajęć prowadzonych ze studentami, stanowiącą rdzeń opisywanych doświadczeń, osadzam w chaosowej teorii struktur dyssypatywnych. Odnosząc przypomnianą teorię do refleksji nad etapami własnej roboty, przyjmuję więc, że dla wystąpienia studenckich epizodów emancypacyjnych znaczące było naruszanie „uporządkowanych” sposobów ich myślenia o kształceniu się jako spełnianiu narzuconych stereotypowych wymagań zewnętrznych, polegających przede wszystkim na biernym pamięciowym przyswajaniu podawanych treści i wiernym ich odtwarzaniu. Tworzyło to obraz kształcenia jako transmisyjnego układu statycznego.

Dla innego osadzania się studentów w układzie dydaktycznym możliwym jako układ dynamiczny, wyłaniający się z zaburzeń równowagi strukturalnej, ważna była ich wyzwalająca refleksja nad własnym miejscem w procesie studiowania, autokrytycyzm, ale też tworzenie skojarzeń myślowych, snucie wyobrażeń, projektów rozwiązań, przejawianie odwagi prezentowania ich we własnym, niestereotypowym języku, dokonywanie przesunięć semantycznych, realizowanie podmiotowych prezentacji. Czynniki te mogły być znaczące dla rozluźniania standardów jako klimatu sprzyjającego opcji nierównowagi w strukturach porządków ujmowania przez studentów świata, edukacji i samych siebie. Być może stanowiło to małe impulsy ku naruszaniu utrwalonych porządków dydaktycznych, służących perspektywicznie udziałowi studentów we współtworzeniu porządków nowych, oddających zmianę ich wizji świata i wytwarzaniu innych sensów własnego kształcenia się. Mogła się tutaj objawiać nieprzewidywalność zmian w systemach złożonych, rola drobnych zaburzeń, prowadzących do nowych, zaskakujących jakości.

„Etap pożegnania”, zamykający moją ponad dziesięcioletnią pracę z kilkunastoma rocznikami studenckimi, zaznaczył się nieoczekiwanymi „wyznaniami lirycznymi” słuchaczy. Ku mojemu zdumieniu okazało się, że szczególnie cenione przez studentów były wielogodzinne zajęcia poświęcone ustnym egzaminom poprawkowym, prowadzone w małych grupach, $w$ formie dyskusji i rozmów dotyczących błędów popełnionych przez nich w pracach pisemnych, często rozbudowane ponad plan zajęć i obowiązującą nas tematykę. Dlaczego? „My wtedy chwytaliśmy i zaczynaliśmy rozumieć, czego nie rozumiemy, a nie można zrozumieć, póki się nie rozumie, czego i dlaczego się nie rozumie [...]. Wydawało się nam, że na egzaminie trzeba coś napisać i egzaminator powinien docenić ten wkład, nawet jeśli odpowiedź nie jest dobra, bo coś się napisało. Dopiero na poprawkowym ogarnialiśmy, że jest inny związek między pytaniami a odpowiedziami i w ogóle w rozmowach ludzi”. Na żartobliwą uwagę nauczycielki, że studenci w chwilach rozstania wypowiadają się pozytywnie o zajęciach, a w toku studiów bywali wobec nich krytyczni (jak i wobec negatywnych pisemnych ocen), odpowiadali, że potrzebne im było samousprawiedliwienie: „My dobrze wiedzieliśmy, że chodziło o to, żeby nas czegoś nauczyć, ale nasze niepowodzenia były przykre, więc chcieliśmy przełożyć je na wykładowcę".

Tego rodzaju rozmowy odbywane wtedy, kiedy wiadomo było, że ja kończę pracę w uczelni, w miejscach zupełnie pozbawionych akademickiego „dostojeństwa” - na 
korytarzach, klatce schodowej, w uczelnianym bufecie - miały otwarty charakter. Zaznaczał się w nich bezkoturnowy kontakt ludzi wspólnej pracy wykonywanej w trudzie i znoju, którzy zmagali się z czymś, a teraz - już zdystansowani, odsuwający na bok instytucjonalną formę i grę - mówią wprost do siebie o sobie i o własnej robocie, odkrywają twarze, wykładają myśli i próbują zastanowić się i zwerbalizować to, w czym uczestniczyli, i co z tego dla nich wynikało.

A bodaj najważniejsze, co wynikało, dotyczyło początków zmian w podejściu do kształcenia się. Studenci ćwiczyli nad sobą, a jednocześnie podejmowali próbę rozstawania się z własnym „zewnętrznym” uczeniem się. Rozumiem je jako poznawanie nieżyciowe, obce, wykonywane pod presją, zadane, a przez to pozorowane, traktowane instrumentalnie i formalnie. Dla uczącego się najważniejsze w tym kontekście było uzyskiwanie etapowych promocji udzielanych przez „innego”, co osadzało się w modusie "muszę, chociaż nie chcę”. Zamiast tego studenci zwracali się ku uczeniu się „wewnętrznemu”. Mam przez nie na myśli poznawanie egzystencjalnie znaczące, dotyczące wyższej troski o siebie, dostrzeganie i krytyczne współtworzenie sensów rzeczywistości i znalezienie się w niej, przepojone własną odpowiedzialnością za stan własnego umysłu z rosnącą podmiotową rolą modusu „ja mogę i chcę" (Rutkowiak 2005).

Natomiast dla nauczycielki akademickiej, przechodzącej przez te doświadczenia, poniekąd przeżywającej ewolucję własnego profesjonalizmu, oznaczały one szansę poznawania meandrów dynamiki kulturowej, przez jaką mogą przedzierać się ludzie borykający się z trudnościami uzyskiwania mentalnej samodzielności i świadomego uczestniczenia w zmienianiu siebie, swojego życia i otoczenia.

\section{Wyniki}

W tradycyjnej dydaktyce wyniki nauczania traktuje się jako rezultat prac nauczyciela osiągany dzięki wypełnieniu jego zamierzeń przez uczniów. W naszej robocie rzecz wypadła inaczej. Odnosiłam wrażenie, że to, co można było uznać za zmiany sygnalizowane przez przedstawione „epizody”, pojawiało się jako przebłyski refleksji studentów dotyczącej siebie i własnego studiowania. Nierzadko ukazywały się obok nauczyciela lub na pograniczu jego intencji i faktycznej studenckiej aktywności uprawianej jakby w zagmatwaniu, gdyż na marginesie wytyczonego programu, ale zarazem odnoszącej się do niego.

Jeśli można mówić o wkładzie nauczycielki, to był to wysiłek przezwyciężania jej własnego oburzenia na braki młodzieży, namysł nad ich źródłami oraz przyjęcie założenia, początkowo intuicyjnego, jeszcze niewiązanego z ideą nauczyciela ignoranta, że studenci mają potencjały rozwojowe często nierozpoznane przez otoczenie, które trzeba ożywiać drogą uprawiania dydaktycznych prób o charakterze rozgrzewek uruchamiających życie umysłu. Łączy się to z rozstawaniem się z tym mitem pedagogiki, w którym dzieli się świat ludzi na dwie nienaruszalne części: 
wiedzących i niewiedzących, dojrzałych i niedojrzałych, zdolnych i niezdolnych (Rancière 1991: XX).

Prowadzone w naszej robocie rozgrzewki wiązały się z możliwościami podważania nawykowego udziału w uczeniu się osadzonym w modelu poznawania jako statyki podawania, przyswajania i odtwarzania - na rzecz dynamiki uprawiania własnego, nierzadko chaosowego, spontanicznego ruchu orientacyjno-poznawczego powiązanego z życiem samym. Ryzykując uproszczenie, powiem, że w ten sposób pojawiała się przestrzeń dla „dydaktycznych struktur dyssypatywnych”. Działo się to dzięki uruchamianiu - także przez samych uczących się - pewnych naruszeń w procesie ich studiowania: $\mathrm{w}$ zmienianiu utartych ról dydaktycznych i ich relacji, wprowadzaniu do wypowiedzi własnego, osobistego języka, w twórczym operowaniu nim, improwizowaniu, samodzielnym dokonywaniu przekładów wykrywanych sensów, próbach penetrowania nieprzejrzystych kontekstów zjawisk, które odbierali jako ważne dla siebie. Owe naruszenia przedstawiłam w „epizodach” z pierwszej części tekstu.

Osiągane w robocie „wyniki” sytuowały się niekiedy bliżej, a niekiedy zaskakująco daleko od nauczycielskich zamierzeń. Zawsze jednak - chociaż często nie wprost - sprzyjały one refleksyjnemu wglądowi w określony aspekt tematyki edukacyjnej. Jaki aspekt? To niejednokrotnie „ustanawiali” sami studenci lub lepiej rozstrzygało się w toku czynionych przez nich prób poznawczych. Rzecz stawała się możliwa wówczas, kiedy poczuli oni przewrotny (być może Kantowski) urok posługiwania się własnym rozumem, co z jednej strony wymaga wysiłku, a z drugiej daje poczucie fascynacji, kiedy już zauważalny jest rys własnej pozycji zmiany przez zaangażowanie poznawcze.

W toku roboty ewoluowały też relacje nauczycielsko-studenckie: początkowy stan „dwóch obozów” przekształcał się w parawspólnotę, która bynajmniej nie była wzorcowo spójna i jednakowo obejmująca wszystkich uczestników wydarzeń. Była jednak połączona zamierzeniami i wysiłkami bliskimi przekonaniu, że poznawanie jest intrygujące i możliwe także dla tych studentów, dla których jeszcze niedawno stanowiło odległą i niedostępną twierdzę zbędnej abstrakcji, formalizmu, nudy, przykrego nacisku zewnętrznych struktur, a przede wszystkim - niemożności.

Czy to, do czego doszliśmy, można nazwać stanem emancypacyjnym? Przyjmując pogląd o pojmowaniu emancypacji jako drogi, a nie jako skończonego stanu, metaforycznie określę nasze wstępne „osiągnięcia” jako „kiełkowanie emancypacyjne”, co kojarzę z Deleuzeańską figurą kłącza (Deleuze, Guattari 1988), gdzie kłącze, dynamicznie wplątane w wielość, szuka - kiełkując - własnej drogi ku światłu.

\section{Podsumowanie}

Przedstawioną wypowiedź zamknę punktową rekonstrukcją osobowej charakterystyki Rancière’owskiego nauczyciela ignoranta, którego „wzór” tylko częściowo aplikowano w tym tekście do zinterpretowania własnej pracy ze studentami, 
kontekstowo osadzonej w określonym etnicznym środowisku ludzi z trudem, także i drogą kształcenia się, przezwyciężających ślady brutalnych krzywd i piętna marginalizacji. Jestem zdania, że zawierają się w nim takie potencjały, które mogą być wykorzystane $\mathrm{w}$ badaniach dydaktycznych nad kształceniem umasowionym, realizowanym na obszarach peryferyjnych. Problematyka ta ma przed sobą niemałą przestrzeń i przyszłość.

Powiedzmy więc, że nauczyciel ignorant w ujęciu Rancière’a to ten, kto:

- pielęgnuje w sobie przekonanie, że wszyscy ludzie mają równą inteligencję. Wobec uczniów oznacza to równość ich potencjałów uczenia się. Zasada ta nie wyraża prawdy, ponieważ w rzeczywistości inteligencje są nierówne i różne. Jest to tylko opinia jako odczucie, które formułujemy o faktach obserwowanych powierzchownie (Rancière 1991: 45-46). Pomimo to może ona być traktowana jako inspiracja do formułowania hipotez weryfikowanych przez osiągane wyniki dydaktyczne;

- prowadzi się powściągliwie, nie postrzega samego siebie jako wszystkowiedzącego mędrca, który zawsze jest niezbędny uczniom. Widzi się natomiast jako tego, kto uczy się razem z nimi, ponieważ wie, że nauczyciel nie zawsze umie to, czego chce nauczyć, a nauczanie bez jego ingerencji też jest możliwe (Rancière 1991: 101), jeśli pojmuje się je jako impuls do samorozwoju. Tezę tę zilustrował Rancière przykładem działalności pedagogicznej Josepha Jacotoła. W 1840 roku na jego nagrobku wypisano credo „intelektualnej emancypacji”: „Wierzę, że Bóg stworzył ludzką duszę jako zdolną do uczenia siebie przez siebie i bez mistrza" (Rancière 1991: 139);

- pracuje z powagą, nie uznaje nauczania fikcyjnego i mistyfikacji uczenia się przez jego uczniów;

- bardziej czuwa nad tym, czy uczeń szuka, niż weryfikuje to, co student znalazł;

- wie, że nauczyciel, który uporczywie tłumaczy, wstrzymuje ruch myśli samego ucznia, a jemu trzeba dać wolność posługiwania się własnym rozumem;

- odwołuje się do ludzkiego postrzegania świata na wielu poziomach;

- wie, że ciężar poznawania leży po stronie ucznia, gdyż najpierw trzeba się czegoś nauczyć, aby do tego odnosić resztę wiedzy (Rancière 1991: 101);

- zadaje uczniom pytania niesokratejskie, gdyż Sokratesowi chodziło o dochodzenie do prawdy, w którym dyryguje się uczniem, a pytać trzeba o to, co uruchamia arbitralną inteligencję ucznia;

- przyjmuje, że najważniejsze są pytania, które uczeń sam sobie stawia, ponieważ w pytaniach nauczycielskich idzie o przywołanie treści, których oczekuje pedagog;

- akceptuje nieoczekiwane skutki własnych działań i robi to z poczuciem humoru, gdyż wie, iż nie sposób przewidzieć, co z tej roboty wyniknie;

- okazuje czujność wobec własnego demokratycznego stosunku do ludzi, ponieważ wie, że przewaga wiedzy może prowadzić do przewagi nad innymi; 
Rancière widzi nauczyciela ignoranta jako emancypatora. Emancypacja przy tym oznacza dla niego wzięcie własnej inteligencji w swoje ręce i pokierowanie nią, czując w sobie godność człowieka (Rancière 1991: 17).

Jacotot całe swoje podejście traktował jako możliwą "powszechną metodę nauczania", polegającą na komunikacji między dwoma bytami rozumnymi. Wbrew pozorom nie jest to więc metoda dla ludzi biednych, ale dla wynalazców (Rancière 1991: 106), a emancypatorem nie jest ten, kto daje klucz do wiedzy, ale świadomość, co można zrobić ze swoją inteligencją, kiedy rozpatruje się ją jako równą innym. Emancypacja jest świadomością tej równości (Rancière 1991: 39).

\section{Literatura}

Achremczyk S., 2010-2011, Historia Warmii i Mazur, t. 1-2, Olsztyn: Ośrodek Badań Naukowych im. Wojciecha Kętrzyńskiego.

Arendt H., 2000, Kondycja ludzka, tłum. A. Łagodzka, Warszawa: Fundacja Aletheia.

Bendyk E., 2014, Adaptacja, konserwacja czy kolonizacja? Wyzwania podwójnej peryferyjności. dodatek do raportu [w:] B. Fatyga, M. Dudkiewicz, P. Tomanek, R. Michalski, „Kultura pod chmurnym niebem”. Dynamiczna diagnoza stanu kultury województwa warmińsko-mazurskiego. Raport i rekomendacje praktyczne, Olsztyn-Warszawa: Centrum Edukacji i Inicjatyw Kulturalnych w Olsztynie.

Bilińska-Suchanek E., 2000, Opór wobec szkoty. Wzrastanie w perspektywie paradygmatu oporu, Słupsk: Wydawnictwo Pomorskiej Akademii Pedagogicznej.

Czapka E., 2006, Postawy wobec norm regulujących sposób zdobywania środków do życia [w:] Młodzież z województwa warmińsko-mazurskiego. Zagrożenia, szanse, plany życiowe, red. Z. Kawczyńska-Butrym, Olsztyn: Wydawnictwo Olsztyńskiej Szkoły Wyższej im. Józefa Rusieckiego.

Czerepaniak-Walczak M., 2006, Pedagogika emancypacyjna. Rozwój świadomości krytycznej człowieka, Gdańsk: Gdańskie Wydawnictwo Psychologiczne.

Deleuze G., Guattari F., 1988, Kłacze, „Colloquia Communia” nr 1-3.

Fatyga B., Dudkiewicz M., Tomanek P., Michalski R., 2014, „Kultura pod chmurnym niebem". Dynamiczna diagnoza stanu kultury województwa warmińsko-mazurskiego. Raport i rekomendacje praktyczne, Olsztyn-Warszawa: Centrum Edukacji i Inicjatyw Kulturalnych w Olsztynie.

Gdula M., 2013, Smutny boom edukacyjny, Kontakt: dwutygodnik internetowy, https:// magazynkontakt.pl/smutny-boom-edukacyjny/ [dostęp: 10.12.2019].

Grosse T.G., 2002, Przeglad koncepcji teoretycznych rozwoju regionalnego, „Studia Regionalne i Lokalne" nr 1.

Kawczyńska-Butrym Z. (red.), 2006a, Młodzież z województwa warmińsko-mazurskiego. Zagrożenia, szanse, plany życiowe, Olsztyn: Wydawnictwo Olsztyńskiej Szkoły Wyższej im. Józefa Rusieckiego.

Kawczyńska-Butrym Z., 2006b, Problemy i doświadczenia młodzieży. Analiza wywiadów fokusowych [w:] Młodzież z województwa warmińsko-mazurskiego. Zagrożenia, szanse, plany życiowe, red. eadem, Olsztyn: Wydawnictwo Olsztyńskiej Szkoły Wyższej im. Józefa Rusieckiego. 
Kawczyńska-Butrym Z., 2006c, System wartości badanej młodzieży [w:] Młodzież z województwa warmińsko-mazurskiego. Zagrożenia, szanse, plany życiowe, red. eadem, Olsztyn: Wydawnictwo Olsztyńskiej Szkoły Wyższej im. Józefa Rusieckiego.

Kawczyńska-Butrym Z., 2006d, Województwo warmińsko-mazurskie - społeczna specyfika terenu [w:] Młodzieżz województwa warmińsko-mazurskiego. Zagrożenia, szanse, plany życiowe, red. eadem, Olsztyn: Wydawnictwo Olsztyńskiej Szkoły Wyższej im. Józefa Rusieckiego.

Kwaśnica R., 2007, Dwie racjonalności. Od filozofii sensu ku pedagogice ogólnej, Wrocław: Wydawnictwo Naukowe Dolnośląskiej Szkoły Wyższej Edukacji TWP.

Kwieciński Z., 2019, Agnotologia pedagogiczna. Zarys problematyki. Trzy subiektywne opowieści [w:] idem, Grzęzawisko. Eseje z pedagogiki społecznej i krytycznej socjologii edukacji, Toruń: Studio Kropka.

Laclau E., 1996, Emancipation(s), London: Verso.

Malewska E., 2006, Zapaść edukacyjna społeczności wiejskiej w regionie Warmii i Mazur [w:] Sapientia et adiumentum. W trosce o rozwój innych. Studia dedykowane profesorowi Zbigniewowi Kwiecińskiemu, red. J. Michalski, Olsztyn: Wydawnictwo Uniwersytetu Warmińsko-Mazurskiego.

Misiuna B., 1993, Oburzenie. Filozoficzna analiza zjawiska i jej konsekwencje aksjologiczne, Warszawa: Wydawnictwo IFiS PAN.

Nalaskowski A., 1998, Nauczyciele z prowincji u progu reformy edukacji, Toruń: Wydawnictwo Adam Marszałek.

Prigogine I., Stengers I., 1990, Z chaosu ku porządkowi. Nowy dialog człowieka z przyroda, tłum. K. Lipszyc, Warszawa: PIW.

Rancière J., 1991, The Ignorant Schoolmaster. Five Lessons in Intellectual Emancipation, transl. K. Ross, Stanford (CA): Stanford University Press.

Rutkowiak J., 1996, Chaos i porządek jako wymiary funkcjonowania nauczycieli (próba analizy w świetle teorii struktur dysypatywnych) [w:] Demokracja a oświata, kształcenie i wychowanie. Materiały z II Ogólnopolskiego Zjazdu Pedagogicznego, red. H. Kwiatkowska, Z. Kwieciński, Toruń: Polskie Towarzystwo Pedagogiczne.

Rutkowiak J., 2005, Uczenie się jako problem etyczny. O zewnętrznym i wewnętrznym uczeniu się [w:] Uczenie się jako przedsięwzięcie na całe życie, red. T. Bauman, Kraków: Oficyna Wydawnicza „Impuls”.

Sadura P., 2015, Przemiany stylu edukacyjnego klasy ludowej w Polsce, „Edukacja” nr 4.

Sowa J., 2011, Fantomowe ciało króla. Peryferyjne zmagania z nowoczesna formą, Kraków: Universitas.

Springer F., 2016, Miasto Archipelag. Polska mniejszych miast, Kraków: Karakter.

Tarkowska E., Korzeniowska K., 2002, Młodzież z byłych PGR-ów. Raport z badań, Warszawa: Instytut Spraw Publicznych.

Tempczyk M., 1995, Świat harmonii i chaosu, Warszawa: PIW.

Woydyłło-Osiatyńska E., 2010, Prowincjonalizm psychologiczny Polaków [wykład z cyklu „Polska, czyli prowincja” w Centrum im. Profesora Bronisława Geremka w Warszawie].

Zawistowska A., 2012, Horyzontalne nierówności edukacyjne we współczesnej Polsce, Warszawa: Wydawnictwo Naukowe Scholar. 


\section{Streszczenie}

W tekście przedstawiono próbę teoretyzowania funkcjonowania umasowionego szkolnictwa wyższego we współczesnej Polsce, dokonaną przez interpretację doświadczeń własnej pracy akademickiej realizowanej w przykładowych niepublicznych szkołach wyższych, a osadzonej w teorii nauczyciela ignoranta autorstwa Jacquese’a Rancière’a. Opisano uwarunkowania i etapy tej pracy jako: etap oburzenia; etap działań chaosowych - w sensie filozoficznym oraz etap „kiełkowania emancypacyjnego”.

\section{Słowa kluczowe}

nauczyciel ignorant, oburzenie, chaos, „kiełki emancypacyjne”

\section{Summary}

Rancièrian emancipatory interpretations; The experience of academic work in non-state higher education institutions located in the Warmia-Mazury region

The text presents applying of Rancière's "ignorant schoolmaster" theory to academic work interpretation with students of selected nonpublic higher schools of Warmia and Mazury. The depiction features three stages of common activities moves: the first, meeting as a phase of indignation; the second, educating as a phase of chaos - in a philosophical language; the third, phase of "emancipatory sprout".

\section{Keywords}

ignorant teacher, indignation, chaos, "emancipatory sprout" 